\title{
EVALUATION OF SHELF LIFE OF SALTY COOKIES FORMULATED WITH BARU BY- PRODUCTS (Dipteryx alata Vog.)
}

\section{Kelly A. Caetano*, Marcella A. Stahl, Ming C. Chiu, Ana Paula B. Ribeiro, Caroline D. Capitani.}

\begin{abstract}
The aim of the present study was to evaluate the shelf life of salty cookies using oil and partially defatted baru almond flour in the formulation, with the purpose of utilizing baru almond by-products. The centesimal composition of the formulations was initially evaluated. Breaking strength, color and water activity were the parameters analyzed during the shelf life (15 days). However, these physicochemical parameters were found not to be determinant to indicate the shelf life of these cookies, which showed fungi and yeasts on their surface before 21 days
\end{abstract}

\section{Key words:}

baru, cookies, shelf life.

\section{Introduction}

Baru almonds (Dipteryx alata Vog.) are of particular interest by containing high amounts of dietary fiber, unsaturated fatty acids and minerals. Thus, the aim of the present study was to evaluate the shelf life of salty cookies in which the ingredients of their original formulation were replaced with oil and partially defatted baru almond flour.

\section{Results and Discussion}

Formulation 1: $20 \%$ substitution of wheat flour with partially defatted baru flour and $40 \%$ extra virgin olive oil with baru oil; Formulation 2: $80 \%$ substitution of wheat flour with partially defatted baru flour and $85 \%$ extra virgin olive oil with baru oil.

The fatty acid profile of the baru oil used in the cooky formulations showed a high concentration of unsaturated fatty acids ( 75.44\%), with $\sim 48.26 \%$ of them being monounsaturated and $\sim 27.18$ polyunsaturated.

The two cooky formulations contained high concentrations of proteins ( $5 \mathrm{~g} /$ serving size) and total dietary fiber (TDF) (Table 1). Thus, the cookies can be considered to be a food with high fiber content since they have more than $6 \mathrm{~g}$ TDF/100 $\mathrm{g}$ (BRASIL, 2012).

Table 1. Centesimal composition of cookies per serving size (30 g), expressed on a dry basis, and percentage of nutrient adequacy in relation to the recommended daily value (\% DV).

\begin{tabular}{|c|c|c|c|c|}
\hline $\begin{array}{l}\text { Nutrients per } \\
\text { serving size }\end{array}$ & $\begin{array}{c}\text { Formulation } \\
1^{\underline{a}}\end{array}$ & $\% V^{b}$ & $\begin{array}{c}\text { Formulation } \\
2^{\mathrm{a}} \\
\end{array}$ & $\% \mathrm{VD}^{\mathrm{b}}$ \\
\hline Moisture & 4.09 & - & 3.62 & - \\
\hline Ash & 1.55 & - & 1.09 & - \\
\hline Carbohydrates & $10.30 \mathrm{~g}$ & 3.16 & $7.74 \mathrm{~g}$ & 2.37 \\
\hline Proteins & $4.87 \mathrm{~g}$ & 6.48 & $5.86 \mathrm{~g}$ & 7.80 \\
\hline Lipids & $5.77 \mathrm{~g}$ & 12.82 & $7.59 \mathrm{~g}$ & 16.87 \\
\hline $\mathrm{TDF}^{\mathrm{c}}$ & $3.30 \mathrm{~g}$ & 13.56 & $4.07 \mathrm{~g}$ & 16.28 \\
\hline Energy value & $85.65 \mathrm{kcal}$ & 4.28 & $106.52 \mathrm{kcal}$ & 5.32 \\
\hline
\end{tabular}

Table 2. Breaking strength, color, whiteness index and water activity of the cookies.

\begin{tabular}{|c|c|c|c|c|}
\hline $\begin{array}{l}\text { Physico } \\
\text { chemical } \\
\text { parameters }\end{array}$ & $\begin{array}{c}\text { Formulation } \\
1 \\
(\mathrm{t}=1 \text { day })\end{array}$ & $\begin{array}{c}\text { Formulation } \\
2 \\
(\mathrm{t}=1 \text { day })\end{array}$ & $\begin{array}{c}\text { Formulation } \\
1 \\
(\mathrm{t}=15 \text { days }) \\
\end{array}$ & $\begin{array}{c}\text { Formulation } \\
2 \\
(\mathrm{t}=15 \text { days }) \\
\end{array}$ \\
\hline $\begin{array}{l}\text { Breaking } \\
\text { strength }(\mathrm{N})\end{array}$ & $2.05 \pm 0.52$ & $3.32 \pm 0.59$ & $5.52 \pm 0.59$ & $7,01 \pm 0,54$ \\
\hline \multicolumn{5}{|l|}{ Color } \\
\hline$L^{1}$ & $46.05 \pm 1.84$ & $32.85 \pm 1.92$ & $41.09 \pm 2.67$ & $36.08 \pm 2.44$ \\
\hline$a^{2}$ & $5.80 \pm 1.09$ & $3.89 \pm 0.81$ & $5.39 \pm 1.20$ & $3.03 \pm 0.68$ \\
\hline$b^{3}$ & $15.42 \pm 0.89$ & $6.05 \pm 5.15$ & $12.83 \pm 2.37$ & $6.81 \pm 1.99$ \\
\hline $\begin{array}{l}\text { Whiteness } \\
\text { Index }\end{array}$ & $43.57 \pm 1.82$ & $32.29 \pm 2.02$ & $39.39 \pm 2.20$ & $35.61 \pm 2.41$ \\
\hline $\begin{array}{l}\text { Water } \\
\text { activity }\end{array}$ & $0.77 \pm 0.01$ & $0.78 \pm 0.01$ & - & - \\
\hline
\end{tabular}

1'Luminosity; 2,3 Chromaticity coordinates

\section{Conclusions}

- The use of baru oil and partially defatted baru flour in different products can contribute to the reduction of waste and add nutritional value to food, also contributing to the valorization and sustainable development of native areas of Brazil.

- The physicochemical characteristics were not determinant of the useful life of the cookies. The present evaluation permitted us to attribute to the products a shelf life of 21 days after processing. After that period, proliferation of fungi and yeasts was observed, justified by the high water activity of the formulations.

\section{Acknowledgement}

PIBIC/CNPq, FCA-UNICAMP, FEA-UNICAMP, FEQUNICAMP, ITAL.

AOCS. American Oil Chemists' Society. 5ed, Champaign, 2009; BRASIL. Guia Alimentar para a População Brasileira. 2008; BRASIL. RDC no 54, 12 de novembro de 2012; DECAGON. Aqualab, operator's manual. Washington: Decagon Devices, 2003; GOLDESTEIN, J.; NEWBURY, D. E. Plennum Press, 1992. 840p.; JORGE, M.C.; RODRIGUEZ, I.; HOMBRE, R. Alimentaria. v. 36, n. 305, p. 73-76. 1999; LEORO, M. G. V. Dissertação (Mestrado em Tecnologia de Alimentos) - Faculdade de Engenharia de Alimentos, Universidade Estadual de Campinas, 2007; LOHMAN, M., HARTEL, R.W. Journal of the American Oil Chemists' Society, 1994; PROSKY et al. Journal of the Association of Official Analytical Chemists, v.67, p.1044-1052, 1984. 